\title{
THE EUROPEAN CITIZENS' INITIATIVE: A USEFUL INSTRUMENT FOR SOCIETY AND FOR CITIZENS?
}

\author{
LA INICIATIVA CIUDADANA EUROPEA: ¿UN INSTRUMENTO ÚTIL \\ PARA LA SOCIEDAD Y PARA LOS CIUDADANOS?
}

\section{Oana - Mariuca Petrescu ${ }^{1}$}

\begin{abstract}
The necessity to strengthen in a way or another citizen's involvement in the political life of the European Union (EU) is an old issue, but the first unsuccessful attempt to introduce it in a treaty, as a binding legal instrument, took place in 1992. Since then, the importance of involving the Europeans increased constantly taking into account the political, economical, and social realities of the 1990s and 2000s, which determined the leaders of the Member States of the European Union to find the best "political channels" to stipulate both in the primary and in the secondary European legislation, as a "blank insurance" that this right will be officially regulated and promoted at the European level.

Therefore, this article will examine, on the one hand the evolution of the European citizenship and enshrining the political rights for the Europeans, and on the other hand will present a brief history of designing this instrument, if the outcome of these political efforts, namely the European Citizens' Initiative Regulation (ECI), adopted in 2011, represents, after all, a useful or un-useful instrument to be used by the citizens, having also the belief that this supranational instrument will make the citizens more active in using this right of initiative.
\end{abstract}

Key words: Right to initiative, treaties, European Constitution, Regulation, political rights.

RESUMEN: La necesidad de fortalecer, de una u otra manera, el involucramiento de los ciudadanos en la vida política de la Unión Europea (UE) es un asunto antiguo, pero el primer intento fracasado para incluirlo en un tratado, como un instrumento legal vinculante, tuvo lugar en 1992. Desde ese entonces, la importancia de involucrar a los europeos en la vida política ha ido en aumento, tomando en cuenta las realidades políticas, económicas y sociales de las décadas de 1990 y 2000, convenciendo a los líderes de los Estados miembros de la Unión a encontrar los mejores "canales políticos" para estipular, tanto en la legislación europea de carácter primario y secundario, como un "seguro en blanco", que este derecho sería oficialmente regulado y promovido a nivel de la Unión.

Por lo tanto, este artículo examina, por un lado, la evolución de la ciudadanía europea y que consagra los derechos políticos de los europeos, y por otro, presentará una breve historia de la creación de este instrumento, y si el desarrollo final de este esfuerzo político, a saber la Iniciativa Ciudadana Europea (ICE), adoptada el 2011 es o no, después de todo, un instrumento que será usado por los ciudadanos, teniendo también la convicción que este instrumento supranacional fomentará la participación de los ciudadanos, utilizado su derecho a la iniciativa legislativa.

Palabras clave: Iniciativa legislativa, tratados, Constitución Europea, regulación, derechos políticos.

${ }^{1}$ Oana Petrescu is PhD., Postdoctoral Researcher within the European Integration Research Team, Faculty of Law, University of Deusto, Bilbao, Spain, e-mail: oana.petrescu@deusto.es. 


\section{GENERAL CONSIDERATIONS}

The intention of adopting an instrument providing for a set of rights for European citizens, including the right to express themselves, freely and with no difficulties, as "partners" in the decision-making and legislative procedure of the European institutions, was inexistent in the early 1950s, when the European continent was recovering from the severe consequences left by the Second World War, and a daring economic plan, the Marshall Plan², was implemented.

During that period, the politicians were unable to pay attention to the "political voice" of the Europeans due to several important factors such as: the harsh economic and political situation existed at that time in Europe; the instauration of the communist regimes in the Central and Eastern part of Europe ${ }^{3}$; the strong influence of the soviet regime in that part of Europe and its separation from the Western Europe's democratic values, especially when the debate and stipulating of such rights in the national legislations were a tabu subject, while the freedom of expression of the citizens was prohibited.

Except those already mentioned, other social factors (namely: gender employment gap, the lack of social cohesion in adopting the relevant policies for the Europeans or the social inequalities on health outcomes), determined a severe deficiency of communication between the citizens and the authorities involved in the decision-making process both at national level and at the level of the former European Communities, presently the European Union (EU).

In spite of several enlargements of the European Communities, which took place during the 1970s and 1980s, the idea to initiate, adopt and implement the political participation of the citizens in the democratic life of the Communities was still far away from what we know it is today, because other issues were considered to be more important at that time, such as: recovering and consolidating the economies, especially when the countries stopped charging custom duties when they traded with each other, as a result of the new commercial agreements, and especially of the new Common Agricultural Policy $^{4}$, adopted and implemented starting with 30 July 19625; drafting the first plan for a single currency and introducing a new Exchange Rate Mechanism (ERM), as well as adopting a strategic plan to create an economic and monetary union; implementation of a new common regional policy by creating the European Regional Development Fund in December 1974 having as principle aim to help, financially speaking, the poorest regions of the Europe in order to improve their roads and communications, to attract investments and to create more jobs; the fight against the increased pollution in Europe, which determined adopting the first documents in this field, by the European institutions etc.

\footnotetext{
2 Officially known as the European Recovery Program. The Marshall Plan was developed between April 1948 and December 1951, being an U.S. sponsored program designed to rehabilitate the economies of 17 Western and Southern European countries, http://global.britannica.com/EBchecked/topic/366654/Marshall-Plan (accessed February 17th, 2014).

${ }^{3}$ Most of these regimes fall down in 1989 and in the early of 1990s.

${ }^{4}$ http://ec.europa.eu/agriculture/cap-history/index_en.htm (accessed February 17th, 2014).

5 http://europa.eu/about-eu/eu-history/1960-1969/index_en.htm (accessed February 17th, 2014).
} 
Within the same period, it is worth mentioning, political speaking, the adoption of the Decision and Act concerning the election of the representatives by direct universal suffrage in $1976^{6}$, while in 1979, the citizens of nine Member States of the European Communities elected for the first time by direct suffrage ${ }^{7}$ their representatives in the European Parliament, which, from our point of view, marked a crucial moment in developing the political and democratic participation of the Europeans in the former European Community's life. In addition, the first elections represented a meaningful development in the equal representation of women and men, while the strong engagement of the European Parliament to gender problems has been proved by establishing the ad-hoc Committee on Women's Rights and the Committee of Inquiry on the situation of women in Europe ${ }^{8}$.

Practically, this is the moment when the democratic participation of the citizens is officially recognised in a general manner, is spite of the fact that the important role in the legislative process was still given to the European institutions ${ }^{9}$.

It took years since other improvements have been taken through the Treaty on European Union (1992) ${ }^{10}$ and the Treaty of Amsterdam (1999) ${ }^{11}$ by adding new political rights $^{12}$ to those existed already in the benefit of the Europeans. And yet, all these amendments were insufficient to increase the political role of the citizens in the European level policy making as "active partners", even though important changes have been brought to the European institutions, with final aim to grant a stronger "voice" to Europe at international level, from political and institutional viewpoints.

The situation changed in 2009 when the Treaty of Lisbon brought significant amendments, which represent a stone-corner in enhancing the democratic participation of the citizens in the decision-making procedures at the European level as well as an essential supplement of civil rights and tools of direct democracy already granted, such as: the right to petition before the European institutions, bodies, organs and offices; the right of petition to the European Parliament or to the right of appeal to the European Ombudsman ${ }^{13}$ in the cases when the citizens consider that their rights have been violated by the European authorities, lato sensu, or the right to seek information on the activities or

\footnotetext{
6 These documents were signed in Brussels on 20 September 1976 and entered into force on 1 July 1978 after its ratification by all the Member States; STANISLAS (2007) p. 418.

7 Before 1979, the members of the European Parliament were delegated by national parliaments of the Member States.

8 Piodi (2009) p. 1.

9 Petrescu (2013) p. 46.

10 http://eur-lex.europa.eu/en/treaties/dat/11992E/tif/JOC_1992_224_1_EN_0001.pdf (accessed February 17th, 2014).

11 http://eur-lex.europa.eu/en/treaties/dat/11997D/tif/JOC_1997_340__1_EN_0005.pdf (accessed February 17th, 2014).

12 Namely: the right to vote; the right to be elected in the legislative bodies or other representative organs; the right to hold public offices etc.

13 http://www.eu-koordination.de/PDF/steckbrief-european-citizen-initiative.pdf accessed February 17th, 2014).
} 
policies of the European institutions in the framework of the Regulation on access to EU documents ${ }^{14}$, with amendments.

A decisive decision taken in enhancing the political rights of the citizens, as part of their direct involvement in the European legislative process, is considered to be the adoption of the Regulation (EU) no $211 / 2011^{15}$ on the citizens' initiative, based on what the citizens' initiatives are registered on the website of the European Commission starting with 1 April 2012, after fulfilling several criteria, that will be analyse within the present paper.

\section{THE LONG JOURNEY FROM REGULATING THE EUROPEAN CITIZENSHIP TO RECOGNIZING AND EXERCISING THE CITIZENS' POLITICAL RIGHTS}

If the contemporary national citizenship is the product of the modernity, determined by the economic, social and political changes occurred during the eighteenth and nineteenth centuries, which constantly transformed the states, the national communities and the position of the citizens in their societies ${ }^{16}$, the idea of a common citizenship for all the Member States of the European Communities "has been entrenched in the Europe's political leaders' minds ${ }^{17}$ ", in the twentieth century, more precisely by the mid-1960s, where the Western economies were recovered and the right to free movement within the Communities, as well as the right to reside in any Member States having as main purpose to work, including the right to remain in the territory of another Member State after having been employed on that territory, were implemented in three stages within the European Communities, all of these leading to an important decreased of the unemployment rate between 1958 and 1964 in the six founding Member States existed at that time ${ }^{18}$.

The propitious economic situation, the efficient implementation of the free movement of workers, as stipulated for the first time in the Treaty of Paris (ECSC Treaty) and expended later in the Treaty of Rome establishing the European Economic Community (EEC), comprising the right to accept offers of employment, to move freely among the Member States for this purpose and to reside in any Member State if employed there, determined Walter Hallstein ${ }^{19}$ to consider, at the beginning of 1970 s, that all these factors represent "the most spectacular points in the programme which is to lead to the integration of Europe ${ }^{20}$ ", remaining at that time un-answered the question raised from

\footnotetext{
14 Regulation (EC) no 1049/2001 of the European Parliament and of the Council of 30 May 2001 regarding public access to European Parliament, Council and Commission documents, published in JOCE L 145 of 31.05.2001.

15 It was published in JOUE L 65 of 11.03.2011, http://eur-lex.europa.eu/LexUriServ/LexUriServ.do?uri=OJ:L:2011:065:0001:0022:EN:PDF (accessed February 17th, 2014).

16 Chalmers, Davies and Monti (2010) p. 441.

17 MAas (2005) p. 4.

18 Germany, France, Italy, the Netherlands, Belgium and Luxembourg.

19 First President of the European Commission, between from 1958 to 1967.

20 MAas (2005) p. 4.
} 
the constitutional point of view: "do [these points represent] the beginning of a common European «citizenship»?".

The answer came, a little bit later, in 1972 from Hallstein's successor as President of the European Commission, Sicco Mansholt, who argued that the "Community, which has achieved the opening of frontiers for trade in industrial and agricultural goods, must [...] open their [physical borders as well] which still keep [the] citizens apart from one another [including from political standpoint] so that citizens [...] could [finally enjoy their] «European civic [and political] rights»"

Starting from this point, one of the first responds was the joint proposal coming from the Belgium and Italy, who in October 1972 suggested granting few political rights to all the Community citizens, namely the right to vote and be elected in local elections, initiative which was welcomed by the President of the European Commission, at that time, Sicco Mansholt and put in practice seven years later, because of the complexity of the issue and the political mentality existed at that time in Europe.

Between 1973 and 1981, other political steps have been made in completing the image of an unique citizenship granted to all the citizens residing on the same Community territory, by adopting relevant documents such as: a report on European identity concerning the special rights given to the citizens and the need to safeguard principles of representative democracy, rule of law, social justice, and respect for human rights; establishing a working group to study the possibility of a future unique European passport, and the harmonization of the legislation affecting foreigners, including the abolition of the passport controls within the Community territory; a resolution supporting the European citizenship ${ }^{22}$ and finally a proposal for a Council Directive on a right of residence for nationals of Member States in the territory of another Member State ${ }^{23}$, who had as main goal to abolish all remaining restrictions on movement and residence for nationals of Member States.

Staying on the same route of shaping the idea of a European citizenship, it is notably to mention that in 1984 the European Parliament adopted with amendments the Draft Treaty on European Union ${ }^{24}$, also known as "Spinelli draft", which in Article 3 comprised a genuine definition of the future common citizenship, stating that "the citizens of the Member States shall «ipso facto» be citizens of the Union. Citizenship of the Union shall be dependent upon citizenship of a Member State; [...] Citizens of the Union shall take part in the political life of the Union in the forms laid down by the Treaty, enjoy the rights granted to them by the legal system of the Union and be subject to its laws" 25 ". Analyzing the amendment adopted by the European Parliament we can observe that, for the first time, the European citizenship is mentioned expressis verbis in a Draft Treaty and it

21 MAAS (2005) p. 5.

22 This resolution was adopted by the European Parliament, in 1977; MAAs (2001) p. 2, www.yale.edu/leitner/ resources/docs/2001-26.pdf (accessed February 17th, 2014).

23 This proposal was adopted in 1979; http://eur-lex.europa.eu/LexUriServ/LexUriServ.do?uri=OJ:C:1979:207 :0014:0016:EN:PDF (accessed February 17th, 2014).

24 The Draft Treaty was published in JOCE C 77 of 14.02.1984.

25 http://www.cvce.eu/obj/draft_treaty_establishing_the_european_union_14_february_1984-en-0c1f92e8db44-4408-b569-c464cc1e73c9.html (accessed February 17th, 2014). 
belongs to the citizens in parallel with their national citizenship with the condition to be ressortissants (nationals) of one of the former European Community Member States.

The above mentioned amendments together with the White Paper on Completing the Internal Market issued by the European Commission in June $1985^{26}$ (devoting an entire section to the free movement for labour and the professions, with the title "A new initiative in favour of Community citizens"), the European Court of Justice's interpretation on the freedom of movement ${ }^{27}$, and the Schengen agreement adopted in June 1985 (abolishing completely the physical borders between five Member States, including the border controls for their own citizens, as "a major step forward on the road toward European unity $^{28 "}$ ) represented the legal basis for the future "core European citizenship ${ }^{29 ", ~ t h a t ~ w i l l ~}$ be stipulated later in the Treaty of Maastricht (1992).

The geopolitical changes occurred in the Eastern Europe due to the fall of the communist regimes at the end of the 1980s and at the beginning of the 1990s as well as the fall of the Berlin's Wall in October 1989, as a communist symbol of the division between the two German states, the Federal Republic of Germany (FRG) and the Eastern German Democratic Republic (GDR) and the discussions to reunify them into one state, the Federal Republic of Germany ${ }^{30}$, represented the main concerns of the Dublin European Council summit (April 1990), in which context a new "future political union [was taken into account more seriously by stipulating the] European citizenship rights ${ }^{31}$ ”, including granting the political rights.

A joint letter preceding the Dublin summit (April 1990), when France and Germany called for "an [...] Intergovernmental Conference on political union to be held parallel to the conference on economic and monetary union", and the notion of the future European citizenship would be integrated in a future Treaty on the European Union and would also extend specific rights (e.g.: human rights, social and political rights, freedom of movement) in the favour of the Europeans, represented one of the most daring political moments of the 1990s.

In this context, at the end of September 1990, the Spain government, as an active defender of the European citizenship's concept, and based on the general ideas stipulated

\footnotetext{
${ }^{26}$ http://europa.eu/documents/comm/white_papers/pdf/com1985_0310_f_en.pdf (accessed February 17th, 2014). According to paragraph 88 of the White Paper, the European Commission considers to be crucial that until 1992 the obstacles which still exist within the Community territory regarding the free movement of the workers to be removed.

27 MAas (2005) p. 7; Case 139/85 Kempf v Staatssecretaris van Justitie, Judgment of 3 June 1986, published in European Court Reports 1986,

http://eur-lex.europa.eu/LexUriServ/LexUriServ.do?uri=CELEX:61985CJ0139:EN:HTML (accessed February 17th, 2014); Case C-292/89 The Queen v Immigration Appeal Tribunal, ex parte Gustaff Desiderius Antonissen, published in European Court reports 1991, http://eur-lex.europa.eu/LexUriServ/LexUriServ. do?uri=CELEX:61989J0292:en:HTML (accessed February 17th, 2014).

${ }^{28}$ MaAs (2005) p. 8.

29 MAAS (2005) p. 8.

30 The Federal Republic of Germany (FRG) and the Eastern German Democratic Republic (GDR) reunited on 3 October 1990.

31 MaAs (2005) p. 10.
} 
in a document of 1978 entitled "Towards a Europe for Citizens ${ }^{32}$ ", defined in the draft proposal "The road to European Citizenship" the planned European citizenship as an integrated space in which the Europeans play a central and fundamental role, strengthening in the same time the "citizens' feelings of belonging to one legal [and unique] Community", proposal that was supported later by the European institutions during the elaboration of the Maastricht Treaty ${ }^{33}$.

The official recognition of the European citizenship came, at the end, during the Maastricht European Council summit, held on 9 and 10 December 1991, where the final text on this issue was agreed in the early hours of 11 December 1991, after long debates and negotiations between the Member States, having different economic interests and political viewpoints ${ }^{34}$, stipulating in former Article 8 that "(1) The citizenship of the Union is [...] established. Every person holding the nationality of a Member State shall be a citizen of the Union. (2) Citizens of the Union shall enjoy the rights conferred by this Treaty and shall be subject to the duties imposed thereby".

Therefore, the Maastricht Treaty introduced for the first time the legal concept of the European citizenship ${ }^{35}$, as part of the transition from a mainly economic community to a political union, amending the Treaties of Rome, and conferred also a limited number of political rights ${ }^{36}$ with practical and symbolic importance in reducing the European Union's democratic deficit, forming a base for the construction of a genuine European identity ${ }^{37}$ and determining a Union of all these people into a truly meaningful European citizenship ${ }^{38}$.

Five years later, through the Treaty of Amsterdam (1997) many Member States proposed on the one hand to extend the citizenship rights' sphere by adding others, which proved to be unsuccessful, so that the only right recognised and enshrined in former Article $8 \mathrm{~d}$ was the right to write to any of the European "institutions or bodies" and to receive a reply in any of the 11 official languages, existed at that time. And yet these amendments were not enough to support the citizenship to become a key element of Amsterdam and to promote other political rights in the benefit of the citizens, transforming them into real "partners" of the European institutions in the decision making process.

On the other hand, in order to eliminate any doubts that citizenship might use to transform the European Union into a sovereign state, as a federal or co-federal of states, and to weak the national citizenship, the Member States agreed to stipulate expressis verbis in former Article 17 of the Treaty of Amsterdam establishing the European Community that the "citizenship of the Union shall complement and not replace national citizenship", especially

\footnotetext{
32 This report was elaborated by Leonard Clemence "Leo" Tindemans, former prime minister of Belgium between 25 April 1974 and 20 October 1978, http://aei.pitt.edu/942/1/political_tindemans_report.pdf (accessed February 17th, 2014).

33 Chalmers, Davies and Monti (2010) p. 444.

34 MAAS (2005) p. 12.

35 Craig and De Búrca (2011) p. 819.

36 Former Articles 22-25 TEU. We are referring to the right of alien suffrage, the passive and active electoral rights created for the Europeans residing in the host Member States etc.

37 Rostek, Davies (2006) pp. 1 and 6.

38 Horspool, Humpshreys (2010) p. 386.
} 
when the primary feature of citizenship is to conferral certain obligations and rights including political ones ${ }^{39}$. This means that the European Union is a "union of many, but not the creation of a new people $e^{40}$ ", highlighting thus the peculiar nature of such entity.

Even though, incremental changes to the European citizenship have been taken through the Treaty of Nice (2001), by extending the qualified majority voting to free movement of citizens within the European territory, yet this treaty did not added further political rights for the citizens. Nonetheless, it is easy to observe that the Europeans were still unable to participate actively in the political life of EU.

For the first time since 1992, the Laeken European Council summit of December 2001 signified the moment when the need to increase the European Union's democratic legitimacy and to adopt legal instruments for a better democratic scrutiny at all levels of government, represented serious issues which determined the European political leaders to state in the Final Declaration on the Future of the European Union ${ }^{41}$ that "the Union, [as a whole and ] the European institutions [in particular] must be brought closer to its citizens, calling [also] for a clear, open, effective, democratically controlled Community approach ${ }^{42}$ ", including by adding new political rights for the citizens, such as the right to participate effectively in a way or another to the political life of the European Union, which unfortunately was not put into practice until 2009, through the Treaty of Lisbon.

Taking into consideration that the topic of the right to initiate was still pending since the 2001 Laeken summit, because the political leaders did not find the proper way to stipulate it, in 2009 the democratic participation of the citizens in the decision making process was finally enhanced through the Lisbon Treaty, by laying down their political right to initiate proposals and send them to the European Commission only if the legal requirements are fulfil.

As for the European citizenship, the Lisbon Treaty did not introduce important amendments, placing this issue "in the context of a new emphasis on representative and participatory democracy, including a new agenda-setting citizen's initiative ${ }^{43}$ ". The only significant amendment made was to include the European citizenship in the Charter of Fundamental Rights of the European Union, having legally binding, and to redefine the citizenship as a 'bundle of rights'.

The general framework of the newest right officially recognised for the citizens in a treaty could not be completed without mentioning the adoption, at the level of secondary European legislation, of an innovative tool, namely the Regulation (EU) no 211/2011 on the citizens' initiative, which entered into force on 1 April 2012, as part of the active participation of the Europeans in the EU level policy making.

\footnotetext{
39 Rostek, Davies (2006) p. 4.

40 Colombo (2004) p. 24.

41 Annex I attached to the Final Declaration, 2001, p. 20, http://ec.europa.eu/smart-regulation/impact/ background/docs/laeken_concl_en.pdf (accessed February 17th, 2014).

42 Annex I attached to the Final Declaration, 2001, p. 21.

43 Craig and De Búrca (2011) p. 819.
} 
For a better understanding of this new legal instrument, in the following we will analyse it, pointing out in the same time the utility of such instrument, both for citizens and for civil society.

\section{A GENUINE INVOLVEMENT OF THE CITIZENS IN THE POLITICAL LIFE OF THE EUROPEAN UNION. IS EUROPEAN CITIZENS' INITIATIVE A USEFUL INSTRUMENT?}

Before 1976, the political role of the citizens in the legislative process of the former European Communities was quasi - inexistent because of the small number of the legal initiatives to regulate this presence. The situation has been changed in a positive way starting with 1976, when the Decision and Act on European elections by direct universal suffrage by citizens, have been adopted. This is the moment when the democratic participation of the citizens started to be shaped in a more concrete manner ${ }^{44}$, contributing thus to the political development of the European Community ${ }^{45}$ and reducing the democratic deficit.

Later, the Treaty on European Union (1992) and the Treaty of Amsterdam (1999) took further steps in increasing the role of the European Parliament in the decision-making process of the Community, adding new political rights ${ }^{46}$ to the European citizens, having as final goal to reduce as much as possible the democratic deficit. These amendments were insufficient to enhance the political role of the citizens in the legislative process, as "coauthors", but not only as passive beneficiaries of all the changes made in the legislation.

A decisive moment for stipulating clearly the right to initiative for citizens was the Constitutional Treaty (2003) which, among other interesting innovations, provided for the citizens' initiative, whereby a million citizens from a significant number of Member States should sign a petition and submit it then to the European Commission in order to start the legislative process. However, the provisions of this hybrid document were still limited to the role of the principles of participatory and representative democracy regarding the functioning of the European institutions, and the policy-making efforts of the Union itself, not the Member States or to the citizens ${ }^{47}$, but on the other hand it opened the way for a future settlement of this issue.

Once the Constitutional Treaty was withdrawn because of the failure to be ratified by France and the Netherlands in the middle of 2005, another moment in drawing the concept of a "citizens' initiative" is represented by the document "More democracy in Europe $^{48 "}$ issued in 2005 by the Democracy International ${ }^{49}$, in which were inserted visionary

\footnotetext{
44 Petrescu (2013) p. 46; Schnapper (1997) p. 203.

45 Warleigh (2001) pp. 34-35.

46 By political rights we may understand a variety of such rights, namely: the right to vote; the right to be elected in the legislative bodies or other representative organs; the right to hold public offices, the right to petition etc.

47 SHaW (2007) p. 2556.

48 www.more-democracy-in-europe.org/sites/more-democracy-in-europe.org/files/u293/di-aufruf-englisch-2seitig.pdf (accessed February 17th, 2014)

49 Democracy International is a network specialised on European democracy movements.
} 
ideas for that date about the most important elements of the direct democracy (a direct involvement of the citizens in the legislative procedure; the methods to involve the citizens etc.), ideas which have finally been put into practice in 2011, when the Regulation $\mathrm{n}^{\circ} 211$ has been adopted, as the first example of the "transnational participatory democracy", allowing the Europeans to play a more active role in shaping different policies of Europe and to use a "new generation of 'iDemocracy tool for the twenty-first century', more direct and more transnational $[. .$.$] than any participatory procedure before i t^{50}$. In other way of saying, the citizens will participate to the normal political life of the European Union, with no restrictions, exercising fully their rights and with more trust in the democratic system ${ }^{51}$, in which context they will ask the European Commission to submit a legislative proposal "within the framework of its powers", as it is stipulated by Article 11 para. 4 TEU.

After a long and arduous process in recognising the political role of the citizens, the Treaty of Lisbon (2009) provided for in Article 10 para.3 TEU that "every citizen shall have the right to participate in the democratic life of the Union", encouraging on the other hand "the cross-border public debate about [the various] EU policy issues ${ }^{52}$ ", such as: political, education, environment, economic etc.

As concern the previous paragraphs, few comments should be made. The first comment is related to the fact that the article already mentioned uses the words "the citizens shall have the right" and not "might have the right", which from our perspective means a clear and strong signal that the European legislator wanted to give by pointing up the importance of the citizens' involvement in the European political life, and making them more active and responsible for the current problems that they are dealing with daily.

Secondly, the European Citizens' Initiative represents the first and daring legislative instrument of direct democracy participation, an innovative element, with supranational value, because it was adopted by the European Union, as an entity, and not by one or several Member States, creating in the same time an additional direct connection between the European citizens and EU's institutions ${ }^{53}$.

Thirdly, the citizens have eventually recognised this right only regarding the initiatives drafted in the field of secondary European legislation, because, as concern the primary legislation, Article 48 TEU, as amended by the Lisbon Treaty, stipulates clearly which are the revision procedures ${ }^{54}$; who can use the revision procedures and in which conditions; to what extent the subjects can use these procedures; which institutions need to be consulted during the revision procedures or other relevant details etc.

Though the importance of the political rights, in general, and of the electoral rights, in particular, increased constantly since the Treaty of Maastricht (1992), nonetheless a

\footnotetext{
50 Kaufmann (2012) p. 11.

51 Ikeda, Kobayashi, Hoshimoto (2008) p. 78.

52 Background speaking points for Zita Gurmai, MEP: The ECI regulation - the contribution of the European Parliament, held in Barcelona, 25 March 2011, p. 1.

53 García, López, Mincheva, Szeligowska (2012) p. 2.

54 Miller (2012) p. 2.
} 
special tool for citizens to increment their participation in the European political life ${ }^{55}$ was still required.

After two years from the provisions enshrined in Article $24 \mathrm{TFEU}^{56}$, and after adoption of several decisive instruments (resolution of the European Parliament in May 200957, proposal of the European Commission in March 2010), in February 2011 was adopted the Regulation (EU) of the European Parliament and the Council no 211 on the citizens' initiative, in an area of EU competence, which defines the rules and the procedure governing this new legal tool involving the initiative to draft proposals through citizens' committee ${ }^{58}$, and to forward them to the European Commission, as the "decisions shall be taken as openly and as closely as possible to the citizens" (Article 10 para.3 TEU), by observing legal provisions. This instrument fully entered into force one year later, at 1 April 2012.

Introduction of such instrument in a treaty motivated the European Commission to state in the Green Paper published in $2009^{59}$ that "it will add a new dimension to European democracy, complement the set of rights related to the citizenship of the Union and increase the public debate around European politics, helping to bring a genuine European public space", recognizing on this occasion the absence of a European public sphere.

From the theoretical viewpoint, the objective of the Regulation (EU) no 211/2011, with enormous political potential for strengthening the democracy in European Union, is to be clear, simple, user-friendly and proportionate to the nature of the citizens' initiative in order to encourage this participation, to make the Union more accessible and more closer to the citizens, or in other words to make Union "more friendly" in its relation to citizens, being also consistent with the Union's values ${ }^{60}$.

Instead, from the practical perspective, its uniform implementation is depending on the proper measures taken by the citizens' committees throughout the entire procedure and in accordance with the Commission Implementing Regulation (EU) no 1179/2011 of 17 November $2011^{61}$ laying down technical specifications for online collection systems pursuant to Regulation (EU) no 211/2011.

\footnotetext{
55 http://ec.europa.eu/public_opinion/flash/fl_292_sum_en.pdf (accessed February 17th, 2014).

56 Article 24 TFEU provides for that: "The European Parliament and the Council, acting by means of regulations in accordance with the ordinary legislative procedure, shall adopt the provisions for the procedures and conditions required for a citizens' initiative within the meaning of Article 11 of the Treaty on European Union, including the minimum number of Member States from which such citizens must come".

57 European Parliament Resolution of 7 May 2009 requesting the Commission to submit a proposal for a regulation of the European Parliament and of the Council on the implementation of the citizens' initiative, http://www.europarl.europa.eu/sides/getDoc.do?pubRef=-//EP//TEXT+TA+P6-TA-20090389+0+DOC+XML+V0//EN (accessed February 17th, 2014).

58 This committee is considered to be the official "organiser" of the initiative and is responsible for managing the entire procedure. The committee must designate from among its members a representative and a substitute to speak and act on their behalf, which will also the contact persons who will liaise between the committee and the European Commission throughout the procedure, http://ec.europa.eu/citizens-initiative/public/how-it-works/committee.

59 http://eur-lex.europa.eu/LexUriServ/LexUriServ.do?uri=COM:2009:0622:FIN:EN:PDF (accessed February 17th, 2014).

${ }^{60}$ Besson and UtZinger (2008) pp. 185-208.

${ }^{61}$ This instrument has been published in the JOUE L 301 of 18.11.2011, http://eur-lex.europa.eu/ LexUriServ/LexUriServ.do?uri=OJ:L:2011:301:0003:0009:EN:PDF (accessed February 17th, 2014).
} 
Analyzing this subject, one question raised, namely is the European Citizens' Initiative (ECI) a useful instrument both for the citizens and for the civil society? In order to understand such a complex mechanism as better as possible, in what follows we will make a presentation $^{62}$ of the most relevant features of this legal tool, highlighting later the relevance for the citizens and for the society, mentioning, in the end, few examples of initiatives that have already collected the minimum number of signatures in order to be submitted to the European Commission as well as other technical things, taking into account that this instrument represents so far, one of the best and viable legal instruments in the hands of citizens.

First of all, to have a better perception on this issue and to eliminate any confusion that might occur as concern the petition, it is important to make a difference between the citizens' initiative and the mechanism already mentioned which is submitted by the citizens. Thus, the first represents "the legal tool" for the citizens to call directly on the European Commission to propose new legal acts or change existing European legislation, while the petition represents a request to do something or to act in a way or another, submitted either to the European Parliament as stipulated by Article 227 TFEU or to the European Ombudsman in accordance with Article $228 \mathrm{TFEU}$, in all the cases when the citizens invoke the maladministration in the activities of the EU institutions, organs, offices and bodies, without fulfilling pre-conditions in order to submit it, such as: a minimum number of signatures, a time period necessary to collect the signatures, formal guidelines for drafting a proposal, specifically for the citizens' initiative. As we can observe, there are two types of petitions submitted to the European Parliament and to the European Ombudsman, where the only condition is that it must affect the citizens directly and take the form of a request or complaint, but very different from the citizens' initiatives ${ }^{63}$.

Another important difference to make is that while the citizens' initiative or digital right of initiative ${ }^{64}$ was introduced, as a novelty, through the Lisbon Treaty in $2009^{65}$, the right to petition, recognised to the citizens, existed already under the previous treaties, being reiterated in the said Treaty.

Regarding the launching of a European Citizens' Initiative, both the Green Paper issued by the European Commission and the Treaty of Lisbon did not stipulate in a way or another who has the right to start and to promote an initiative. Nevertheless, this controversy has been clarified in the Regulation (EU) no 211/2011, which in Article 3 para.1 states that "the organisers shall be citizens of the Union ${ }^{66 " . ~ B y ~ t h e ~ w o r d ~ " o r g a n i z e r s " ~ o n e ~}$ could understand that we are referring to a citizens' committee, composed of at least seven EU citizens who reside on the territory of at least seven different Member States of the European Union. Regarding the seven members of the citizens' committee, the only rule that counts, in order to register the initiative in a proper manner, is their country of residence, which means that they can have the same or different nationalities.

\footnotetext{
${ }_{62}$ More details can be found on: http://ec.europa.eu/citizens-initiative/public/guide (accessed February 17th, 2014).

${ }^{63} \mathrm{http}: / /$ www.europarl.europa.eu/aboutparliament/en/00533cec74/Petitions.html; https://secure.ombudsman. europa.eu/en/atyourservice/secured/complaintform.faces (accessed February 17th, 2014).

${ }^{64}$ SANGSARI (2003) p. 1.

${ }^{65}$ http://ec.europa.eu/citizens-initiative/public/faq\#q12 (accessed February 17th, 2014).

${ }^{66}$ GŁogowski, Maurer (2013) p. 10.
} 
On the other hand, the non - EU citizens cannot be part of a citizens' committee, because the said Regulation also mention that "the organisers shall be [composed of] citizens of the Union [...]" (Article 3 para.1), meaning that it is not enough for the non-EU citizens to reside on the European territory but also they have to have the citizenship of one of the $28 \mathrm{EU}$ Members States, if we take into account the accession of Croatia to the European Union, in July 2013.

As for the members of the European Parliament (MEPs), they cannot be counted among the 7 citizens needed to register the initiative on the official website of the European Commission, that is to say that MEPs cannot be founders of the proposed initiative but they can be counted among the total members of that citizens' committee, because the presence of these members is an important political factor for enhancing the perception and public awareness on the proposed initiative, as it happened in several cases, such as: "End Ecocide in Europe: A Citizens' Initiative to give the Earth Rights ${ }^{67}$, which was supported by the members of the European Parliament from Germany, Austria and France or the initiative "Fraternité 2020 - Mobility. Progress. Europe ${ }^{68}$ ". Supported by the members of the European Parliament from France, Germany, Belgium, Austria, Spain, United Kingdom and Lithuania ${ }^{69}$. Furthermore, the usefulness of this transnational instrument determined many members of the European Parliament to get involved in supporting the citizens' initiatives ${ }^{70}$, no matter if they have collected or not the necessary number of signatures to be forwarded then to the European Commission. Taking into account this context, we can say that this instrument proved to be a bold and useful tool for the European political leaders, so far.

Elaborating an initiative by its promoters ${ }^{71}$, in general terms and not as a proper draft law, implies observing of several technical details in order to ensure a good promotion of the initiative and its visibility, among which we can mention: the title should have maximum 100 characters, otherwise would be difficult to understand the main goal of the initiative; the subject-matter, should have maximum 200 characters and should be written in a clear and comprehensive manner; the description of the objectives on which the European Commission is invited to take attitude should have maximum 500 characters; the personal details of the 7 members of the citizens' committee (e.g.: full names, postal addresses, nationalities and dates of birth), indicating also the name of the representative and the substitute as well as their E-mail addresses; all sources of funding and support for the proposed initiative worth more than $500 €$ per year and per sponsor; the address of their website, which from our perspective represents a good opportunity to add more information about the background of the initiative, the aim, the objectives, the target group envis-

${ }^{67}$ http://ec.europa.eu/citizens-initiative/public/initiatives/ongoing/details/2013/000002 (accessed February 17th, 2014).

68 http://en.fraternite2020.eu/MEPs.html (accessed February 17th, 2014).

69 All data regarding various citizens' initiatives mentioned already and supported by the members of the European Parliament are updated until 17.02.2014.

70 For example, only for two initiatives (Unconditional Basic Income (UBI) initiative and Right2water initiative, http://ec.europa.eu/citizens-initiative/public/welcome (accessed February 17th, 2014)) almost 109 members of the European Parliament have given their support.

71 http://ec.europa.eu/citizens-initiative/public/faq\#q12 (accessed February 17th, 2014). 
aged, the partners from different countries and the sponsors, the status of the signatures etc.; an annex of maximum $5 \mathrm{MB}$, in the form of leaflet, flyer or brochure, comprising detailed information about this initiative and/or a draft legal act with maximum $5 \mathrm{MB}$, as the final outcome of the initiative to be forwarded to the European Commission, as the final phase of this proceeding.

Once drafted, the initiative is registered on the official website of the European Commission, and the organisers will have one year to collect at least one million of signatures, coming from at least one quarter of $28 \mathrm{EU}$ Member States (representing 7 or more Member States). In this regard, the European Commission will make available open source software to be used by the organisers and will adopt clear, undoubtful technical specifications in order to help building of their collection system. As concern the minimum number of signatories per member country, it is provided for in the Annex I of the said Regulation.

As concern the signatures collected either on paper or online, few explanations should be added, as follows. If they are collected on paper, the signatures must comply with the models for the statement of support provided for in Annex III of the Regulation, and if they are collected online, and prior to initiating the collection of the signatures, the organisers must ask the relevant national authority of the Member State, where the data will be stored, to certify their online collection system in accordance with Article 6 para. 2 of Regulation, with a deadline to reply of one month.

After collecting in one year, the number of signatures required, the citizens' committee will submit them again to the relevant national authority in each country, for a careful verification and certification, within a period of three months ${ }^{72}$. Thus, the national authorities should deliver certificates indicating the number of the valid signatures collected. To this end, the national authorities will use appropriate checks to verify the statements, which can include random sampling, as there are no rules specifying the criteria for the verification of the statements.

Subsequently obtaining the certificates from the national authority, the organisers finally submit their initiative to the European Commission that will have three months to examine it and to decide how to react, issuing at the end a press release in which it will explain its conclusions on the proposed initiative, what action it intends to take, if any, and its reasoning. During this period, the European Commission will meet the organisers at an appropriate level so that they can have the opportunity to explain the issues inserted in their initiative, while a public hearing organised at the European Parliament might occur in order to present their initiative, as it was the case of the initiative "Right 2 water" when a public hearing took place on 17 February 2014 at the premises of the European Parliament.

In light of the foregoing, it is important to add few comments in order to ensure o better understanding of this complex instrument, as follows:

\footnotetext{
${ }^{72}$ So far, three initiatives have been declared having reached the target of one million signatures in the EU in at least seven Member States, as follows: "Right2Water" also known as "Water and sanitation are a human right! Water is a public good, not a commodity!" (1,884,790 signatures), "One of us" (1,897,588 signatures), and "Stop Vivisection" (1,326,807 signatures).
} 
a. After verifying the technical conditions, the European Commission will take its decision based only on a political analysis considering the necessity, the importance and the utility of the initiative for the entire European civil society; if the European Commission decides to reject the proposed initiative, neither the Lisbon Treaty nor the Regulation mention any means of appeal against this decision, which means that this institution has the final "political word".

b. Regarding the minimum age required to organise and to support an initiative, this is the voting age for the European Parliament elections, which currently is 18 years in every country, except Austria, where it is 16 years and "the Spanish Autonomous Community of Catalonia ${ }^{73}$ ", while the reason for admitting such indirect exception was considered by the Committee on Petitions of the European Parliament an opportunity "to encourage younger citizens' participation in the democratic life of the Union ${ }^{74 "}$ and not an obstacle for the youngers to be part of such European movement.

c. If the European Commission is agreed with the initiative, the citizens' committee has to ask for the registration of their initiative in one of the official languages of the European Union and in an online registry ${ }^{75}$ made available by the European Commission, which has a period of two months to answer. If the initiative is registered in good conditions, the organisers have the responsibility, and not the European Commission, to add translations of their initiative in any other official languages, as it was in practice the case of several initiatives, e.g.: "European Initiative for Media Pluralism"76" or "Do not count education spending as part of the deficit! Education is an investment! 77 " etc.

From this rule, there are exceptions when the European Commission has the right to refuse the registration of the proposed initiative when: the composition of the citizens' committee does not follow the general rules enshrined in the Regulation; the initiative is manifestly outside the scope of European Commission's competences to propose legislation or it is manifestly abusive, frivolous or vexatious or it is manifestly contrary to the EU's fundamental democratic values and principles stipulated in Article $2 \mathrm{TEU}^{78}$. In the case of subsisting one or more of these cases the European Commission will inform the organizers about its decision to deny the registration of the proposed initiative and also about the possible judicial and extra-judicial remedies available, including the possibility to bring the

\footnotetext{
73 García, López, Mincheva, Szeligowska (2012) p. 10.

74 http://www.europarl.europa.eu/sides/getDoc.do?language=EN\&reference=A7-0350/2010 (accessed February 17th, 2014).

75 http://ec.europa.eu/citizens-initiative/public/registration/ (accessed February 17th, 2014).

76 It was registered initially in English, and then translated in other 15, http://ec.europa.eu/citizens-initiative/ public/initiatives/ongoing/details/2013/000007 (accessed February 17th, 2014).

77 It was registered initially in Greek, and then translated in other 7 languages, http://ec.europa.eu/citizensinitiative/public/initiatives/ongoing/details/2013/000006 (accessed February 17th, 2014).

78 Brochure “The European Citizens' Initiative”, The Greens/EFA in the European Parliament, Brussels, 2011, p. 7, http://aei.pitt.edu/33631/1/wp24_EG.pdf (accessed February 17th, 2014).
} 
case before the Court of Justice of the European Union, as judicial remedy, or before the European Ombudsman, as extra-judicial remedy.

Practically speaking, since April 2012 and until 17 February 2013, 17 initiatives $^{79}$ have already been rejected, for example: "One Million Signatures For "A Europe Of Solidarity"; "The Supreme Legislative \& Executive Power in the EU must be the EU Referendum as an expression of direct democracy" or "Enforcing self-determination Human Right in the EU", where the main reason for rejection was non-fulfilment of the conditions laid down in Article 4 para. 2 of the Regulation. Alternately, if the organisers will respect in the future the conditions stipulated in the Regulation, and will redraft the proposals in a proper manner there are no reasons, from our point of view, for the European Commission to refuse again the registration of such initiatives.

Starting with 1 April 2015 and every 3 years after this moment, the European Commission will present a report on the implementation of this Regulation, pointing out the problems already identified during the implementation of this new instrument, stressing the strong and the weak points of it, and bringing the improvements and amendments to the Regulation, as the case may be etc.

Sharing the opinion expressed in the doctrine $e^{80}$, we consider that the European Citizens' Initiative is a very useful instrument for the society because it introduces a new form of public participation within the EU's multi-level politics framework, adding a new dimension to the European democracy, complementing the set of rights related to the citizenship of the Union and increasing the public debate around the European politics, helping in the same time to build a genuine European public space. Its implementation will reinforce citizens' and organized civil society's involvement in shaping of EU policies, without being manifestly against the values of the Union.

Both at European and national levels, the role of the citizens in the society, including by giving the possibility to promote proposals, is recognised in the secondary European legislation as well as in their fundamental or specific laws. Much more, the citizens' initiative is seen as the modality in which people can participate actively in the political life of the European Union and in the interest of others (or in other way of saying "by citizens, for citizens") and also of their own state, by establishing new rules.

On the other hand, this new legal instrument allows for the greatest political involvement of the citizens in the decision-making process of the European Union from the modern history of direct participation ${ }^{81}$. Furthermore, using this instrument will bring only benefits to all Europeans, if we take into account that a minority of citizens, represented by the citizens' committee, has the right to propose to the European general public, the adoption of a new law or modifying an existing legislative act if applicable, which means a lot if we are thinking that until this Regulation the citizens did not have legal tools to influence the legislative process, in a way or another.

\footnotetext{
79 http://ec.europa.eu/citizens-initiative/public/initiatives/non-registered (accessed February 17th, 2014).

80 Schnellbach (2001) p. 1; Cărăuşan (2011) p. 20.

81 García, López, Mincheva, Szeligowska (2012) p. 63.
} 
Furthermore, this Regulation is innovative for various reasons: it is the first example of a transnational participatory mechanism based on the mobilisation of the citizens at European scale; it has a truthful potential to change the existing relations between the European civil society and EU institutions by making them more opened and cooperative and finally, although this mechanism exists in different constitutional European or American systems, it does not exist in the international arena, so $\mathrm{far}^{82}$.

Eventually, to have a complete image of this topic, in the following we will present few of the successful initiatives that have already collected the minimum number of signatures in at least seven Member States and in the same time more than one million signatures, which demonstrates the strong political intention of the citizens to change something at the European level for their own good and for the future generations, and the efficient organization of the citizens' committees that have conducted intense awareness campaigns in written and digital media and have organised meetings, workshops and seminars explaining the aim, the objectives and the target groups of their initiatives being led by the motto "we can change something for ourselves and for the rest of the citizens".

Thus, the first initiative that has reached the target imposed by the ECI Regulation before its deadline 1 November 2013 is "Right2Water", who consider "water and sanitation as a public good ${ }^{83}$ ". It was registered on 10 May 2012, having as main scope "to propose legislation implementing the human right to water and sanitation as recognised by the United Nations, and promoting the provision of water and sanitation as essential public services for all”. The initiative has been drafted and then translated in 24 languages, collecting at the end 1.857 .605 of signatures, which have been verified and certified by the relevant national authority, in accordance with the provisions of the Regulation.

As the result has been positive, the initiative was forwarded to the European Commission which until 10 March 2014 will examine it and will decide how to react, including asking for more information if applicable, or in the worst case, will reject the initiative, for the reasons mentioned in the present paper. Meanwhile, a public hearing in this case took place on 17 February 2014 at the premises of the European Parliament, being chaired by the Environment Committee, involving the Petitions Committee (PETI), the Internal Market and Consumer Protection Committee (IMCO), and the Development Committee (DEVE).

The second successful initiative registered on the website of the European Commission on 11 May 2012 is "One of us ${ }^{84 ", ~ s e e k i n g ~ t o ~ e n d ~ E U ~ f i n a n c i n g ~ o f ~ a c t i v i t i e s ~ w h i c h ~}$ presuppose the destruction of human embryos. It collected 1.897 .588 signatures until 1 November 2013 in 20 Member States, due to its good organization and efficient awareness campaigns made by the organizers, being considered "a historical step forward in the protection of life in Europe ${ }^{85}$ ". It was supported by many non-governmental organizations, churches, politicians, members of the European Parliament and civil society leaders, while

82 García (2013) p .6.

83 http://ec.europa.eu/citizens-initiative/public/initiatives/ongoing/details/2012/000003; http://www. right2water.eu/ (accessed February 17th, 2014).

${ }^{84}$ It was registered initially in Italian, and then translated in other 23 languages. For more details see http:// ec.europa.eu/citizens-initiative/public/initiatives/finalised/details/2012/000005; http:/www.oneofus.eu/.

85 http://www.oneofus.eu/initiative-explanation/ (accessed February 17th, 2014). 
its goal is "to greatly advance the protection of human life from conception in Europe within the possibilities of the competency of the EU". So far, a public hearing in the European Parliament has not been established, which makes us to believe that soon after the 1 March 2014, such hearing might take place.

Finally the last initiative that collected 1.326 .807 signatures is "Stop Vivisection" having as main purpose to eliminate as much as possible the animal experimentation. Thus, the initiative, translated in all 24 languages and supported by many NGOs in the field of protection of animals, including the Brigitte Bardot Foundation, "gives citizens the opportunity to say "No" to animal experimentation and asking [in the same time] the European Commission to abrogate" in a urgent manner "the Directive 2010/63/EU on the protection of animals used for scientific purposes ${ }^{87}$ and to present a new proposal that" prohibits "animal experimentation" and "to take into consideration a different scientific approach, geared to protect human beings and animals' rights". Similar to the "One of us" initiative, a public hearing in the European Parliament has not been established, which makes us to believe that soon after the 1 March 2014, such hearing might take place.

The successful of the three initiatives, briefly described above, to collect the minimum number of signatures and more than that made the Vice-President Maroš Šefćovič to say that: "I am greatly encouraged by the fact that three such diverse ECIs may have passed the threshold of success. It proves that this very ambitious and unique experiment in transnational participatory democracy has captured the imagination of people across Europe".

\section{CONCLUSIONS}

The goal of the present study was to analyze the beginnings of the European citizenship and the long way of regulating such benefit for citizens, economic, political and social speaking, as well as the evolution of the political rights of the citizens from recognizing few political rights (the right to vote in the direct suffrage, the right to petition) to the newest political right enshrined in a treaty, namely the right to initiative, strengthening thus the participation of citizens in the European political life and a normal development of the European civil society.

After the failure of the Convention on the Future on Europe from $2002^{88}$, known as the European Convention, which stipulated for the first time the right to initiative for citizens in former Article $45^{89}$ (The principle of representative democracy), the Lisbon Treaty

\footnotetext{
86 http://ec.europa.eu/citizens-initiative/public/initiatives/finalised/details/2012/000007; http://www. stopvivisection.eu/ (accessed February 17th, 2014).

87 It was published in JOUE L 276 of 20.10.2010,

http://eur-lex.europa.eu/LexUriServ/LexUriServ.do?uri=OJ:L:2010:276:0033:0079:en:PDF (accessed February 17th, 2014).

88 This Convention was a body established by the European Council in December 2001 to produce a draft Constitution for the European Union for the Council to finalise and adopt and finished its work in July 2003 with their Draft Treaty establishing a Constitution for Europe.

${ }^{89}$ According to this article "every citizen shall have the right to participate in the democratic life of the Union. Decisions shall be taken as openly as possible and as closely as possible to the citizen ”.
} 
represents the second major European treaty that recognises doubtfully and clear this normal political right by adopting, within its secondary legislation, the Regulation (EU) $n$ 211/2011, as a brand new transnational instrument, with principal goal to consolidate democracy in Europe, its democratic values and foundations.

From other perspective, we strongly believe that the proper implementation of this instrument will bring only benefits both for the European Union, as an entity, and for almost 502 million citizens, which starting with 1 April 2012 are acting as "partners", as we prefer to say, in the European legislative process, but not as main actors, by promoting relevant initiatives for the European civil society, with cross-border element, and encouraging debates on issues in various fields of activity, such as: education, environment, taxes, economy, etc.

From the perspective of the democratic theory, the European Citizens' Initiative is important for the society because it is often claimed that the European Union suffers from a democratic deficit which is considered to have its basis both in a community deficit and in a demos deficit.

Analysing the present paper, one question raised, whether this instrument can have the power to contribute in a decisive manner to the trans-European debates on the Union issues beyond the reticence attitude existed until the adoption of the Regulation (EU) $n^{\circ}$ $211 / 2011$, as concern the active involvement of the citizens ${ }^{90}$. Responding to this question, we believe that if this new democratic tool will be implemented properly, with no gaps or other shortcomings, it will have all the chances "to become a policy-creating instrument that will [change the citizens' life in a better and efficient way and will also] improve citizens' influence in the EU political context by reinforcing the exchange of civic competence and fostering civic inclusion at a supranational level ${ }^{91 "}$.

Finally, the last part of the research paper analysed certain successful initiatives that have already collected the number of signatures stipulated by the Regulation, hoping that in the coming weeks other initiatives will gather this minimum number and will be send to the European Commission, taking into account that each of them can change the present life of the European society, can bring something new to the Europeans' life, in order to make it simpler, clearer, wealthier, healthier and better.

\section{BIBLIOGRAPHY}

Besson, Samantha and Utzinger, André (2008): “Toward European Citizenship", Journal of Social Philosophy, vol. 39 No 2, pp. 185-208.

Bouza García, Luis (2013), The Significance of the European Citizens' Initiative for PanEuropean Participatory Democracy, International IDEA publications, pp. 5-29.

Bouza García, Luis; Cuesta López, Víctor; Mincheva, Elitsa; Szeligowska, Dorota

(2012): “The European Citizens' Initiative - A First Assessment", College of Europe, Bruges, pp. 6-52.

90 Głogowski \& MaUrer (2013) p. 25.

91 Hristova-Valtcheva (2008) p. 116. 
CăRĂUŞAN, Mihaela (2011): The European Citizens' Initiative Democracy in the European Union, European Integration - Realities and Perspectives, Conference proceedings, 2011, pp. 19-26.

Chalmers, Damian; Davies, Gareth and Monti, Giorgio (2010): European Union Law: Cases and Materials (Cambridge, Cambridge University Press, second edition).

Colombo, Alessandro (2004): “The Principle of Subsidiarity and European Citizenship”, Vita e Pensieri, pp. 1-85.

Craig, Paul and De Búrca, Gráinne (2011): EU Law, text, cases and materials (Oxford, Oxford University Press, fifth edition).

GŁogowski, Paweł \& Maurer, Andreas (2013): "The European Citizens' Initiative - Chances, Constraints and Limits”, Political Science Series no 134, pp. 7-27.

Horspool, Margot, Humpshreys, Matthew (2010): European Union Law (Oxford, Oxford University Press, sixth edition).

Hristova-Valtcheva, K. (2008): “European Citizens' Initiative: Is a Bottom Up Process Possible?” in Kolarova, R. and Hristova-Valtcheva, K. (eds), Citizens' Europe? Reflections on the Implications of the Lisbon Treaty (Sofia, Bulgarian European Community Studies Association).

Ikeda Ken’ichi, Kobayashi Tetsuro, Hoshimoto Maasa (2008): “Does political participation make a difference? The relationship between political choice, civic engagement and political efficacy", Electoral Studies no 27, pp. 77-88.

Kaufmann, Bruno (2012): The European Citizens' Initiative Pocket Guide, Initiative and Referendum Institute Europe and the Green European Foundation Belgium, pp. 9-82.

MaAs, Willem (2001): The Politics of European Rights For Panel 15-5, The Construction of Individual Rights in the European Union, pp. 1-18.

MaAs, Willem (2005): “The Evolution of EU Citizenship”, Memo for Princeton workshop on The State of the European Union, Volume 8, pp. 1-17.

Petrescu, Oana - Mariuca (2013): "The Political Citizenship in the Context of the Lisbon Treaty”, Romanian Journal of European Affairs, vol. 13, No 1, pp. 44-56.

PIODI, Franco (2009): "Towards direct elections to the European Parliament", CARDOC journals No 4, pp. 5-34.

Rostek Karolina, Davies Gareth (2006): "The impact of Union citizenship on national citizenship policies", EIoP, pp. 2-54.

Sangsari, Marcel (2013): “The European Citizens' Initiative: An early assessment of the European Union's new participatory democracy instrument", Carleton University, pp. 1-13.

SCHnAPper, Dominique (1997): The European Debate on Citizenship (Portland, Daedalus collection, The MIT Press).

SChNellbaCH, Christoph (2001): “The European Citizens' Initiative: a useful instrument for public participation?”, CAP Perspectives, No 3, pp. 1-3.

SHAW, Jo (2007): "E.U. Citizenship and political rights in an evolving European Union", Fordham Law Review, vol. 75, Issue 5, pp. 2549-2578.

STANISLAS, Adam (2007): Electoral rights under the review of the European Court of Justice: judicial trends and constitutional weaknesses, CYELP 3. 
Vaughne, Miller (2012): “Recent EU Treaty Amendments and UK Ratification”, Standard notes SN/IA/6503, International Affairs and Defence Section, pp. 1-5.

Warleigh, Alex (2001): "Purposeful Opportunists? EU institutions and the Struggle over European Citizenship", in Richard Bellamy and Alex Warleigh, Citizenship and Governance in the EU (London, Continuum).

\section{LEGAL RULINGS CITED}

Annex I attached to the Final Declaration, 2001.

Commission Implementing Regulation (EU) no 1179/2011 of 17 November 2011, published in the JOUE L 301 of 18.11.2011.

Draft Treaty was published in the Official Journal of the European Communities, no C 77/33, 1984.

Regulation (EC) no 1049/2001 of the European Parliament and of the Council of 30 May 2001 regarding public access to European Parliament, Council and Commission documents, published in JOCE L 145 of 31.05.2001.

Regulation (EU) no 211/2011 on the citizens' initiative, published in JOUE L 65 of 11.03.2011.

Treaty of Amsterdam (1999).

Treaty of Lisbon (2009).

Treaty of Maastricht (1992).

Treaty on the Functioning the European Union (2009).

\section{JURISPRUDENCE CITED AND OTHER SOURCES}

Background speaking points for Zita Gurmai, MEP: The ECI regulation - the contribution of the European Parliament, held in Barcelona, 25 March 2011.

Brochure “The European Citizens' Initiative”, The Greens/EFA in the European Parliament, Brussels, 2011.

Case 139/85 Kempf v Staatssecretaris van Justitie, Judgment of 3 June 1986, published in European Court.

Case C-292/89 The Queen v Immigration Appeal Tribunal, ex parte Gustaff Desiderius Antonissen, published in European Court reports 1991.

\section{SOURCES ON THE INTERNET}

eur-lex.europa.eu/LexUriServ/LexUriServ.do?uri=OJ:L:2011:065:0001:0022:EN:PDF (accessed February 17th, 2014).

http://aei.pitt.edu/33631/1/wp24_EG.pdf (accessed February 17th, 2014).

http://aei.pitt.edu/942/1/political_tindemans_report.pdf (accessed February 17th, 2014).

http://ec.europa.eu/agriculture/cap-history/index_en.htm (accessed February 17th, 2014).

http://ec.europa.eu/citizens-initiative/public/faq\#q12 (accessed February 17th, 2014).

http://ec.europa.eu/citizens-initiative/public/guide (accessed February 17th, 2014). 
http://ec.europa.eu/citizens-initiative/public/how-it-works/committee (accessed February 17th, 2014).

http://ec.europa.eu/citizens-initiative/public/initiatives/finalised/details/2012/ 000005(accessed February 17th, 2014).

http://ec.europa.eu/citizens-initiative/public/initiatives/finalised/details/2012/000007 (accessed February 17th, 2014).

http://www.stopvivisection.eu/ (accessed February 17th, 2014).

http://ec.europa.eu/citizens-initiative/public/initiatives/non-registered (accessed February 17th, 2014).

http://ec.europa.eu/citizens-initiative/public/initiatives/ongoing/details/2013/000002 (accessed February 17th, 2014).

http://en.fraternite2020.eu/MEPs.html (accessed February 17th, 2014).

http://ec.europa.eu/citizens-initiative/public/initiatives/ongoing/details/2013/000007 (accessed February 17th, 2014).

http://ec.europa.eu/citizens-initiative/public/initiatives/ongoing/details/2013/000006 (accessed February 17th, 2014).

http://ec.europa.eu/citizens-initiative/public/initiatives/ongoing/details/2012/000003 (accessed February 17th, 2014).

http://ec.europa.eu/citizens-initiative/public/registration/ (accessed February 17th, 2014). http://ec.europa.eu/citizens-initiative/public/welcome (accessed February 17th, 2014). http://ec.europa.eu/public_opinion/flash/fl_292_sum_en.pdf (accessed February 17th, 2014).

http://ec.europa.eu/smart-regulation/impact/background/docs/laeken_concl_en.pdf (accessed February 17th, 2014).

http://eur-lex.europa.eu/en/treaties/dat/11992E/tif/JOC_1992_224__1_EN_0001.pdf (accessed February 17th, 2014).

http://eur-lex.europa.eu/en/treaties/dat/11997D/tif/JOC_1997_340__1_EN_0005.pdf (accessed February 17th, 2014).

http://eur-lex.europa.eu/LexUriServ/LexUriServ.do?uri=CELEX:61985CJ0139:EN:HTML (accessed February 17th, 2014).

http://eur-lex.europa.eu/LexUriServ/LexUriServ.do?uri=CELEX:61989J0292:en:HTML (accessed February 17th, 2014).

http://eur-lex.europa.eu/LexUriServ/LexUriServ.do?uri=COM:2009:0622:FIN:EN:PDF (accessed February 17th, 2014).

http://eur-lex.europa.eu/LexUriServ/LexUriServ.do?uri=OJ:C:1979:207:0014:0016:EN:P DF (accessed February 17th, 2014).

http://eur-lex.europa.eu/LexUriServ/LexUriServ.do?uri=OJ:L:2010:276:0033:0079:en:P

DF (accessed February 17th, 2014).

http://eur-lex.europa.eu/LexUriServ/LexUriServ.do?uri=OJ:L:2011:301:0003:0009:EN:P

DF (accessed February 17th, 2014).

http://europa.eu/about-eu/eu-history/1960-1969/index_en.htm (accessed February 17th, 2014). 
http://europa.eu/documents/comm/white_papers/pdf/com1985_0310_f_en.pdf (accessed February 17th, 2014).

http://global.britannica.com/EBchecked/topic/366654/Marshall-Plan (accessed February 17th, 2014).

http://www.cvce.eu/obj/draft_treaty_establishing_the_european_union_14_ february_1984-en-0c1f92e8-db44-4408-b569-c464cc1e73c9.html (accessed February 17th, 2014).

http://www.eu-koordination.de/PDF/steckbrief-european-citizen-initiative.pdf (accessed February 17th, 2014).

http://www.europarl.europa.eu/aboutparliament/en/00533cec74/Petitions.html (accessed February 17th, 2014).

http://www.europarl.europa.eu/sides/getDoc.do?language=EN\&reference=A7-0350/2010 (accessed February 17th, 2014).

http://www.europarl.europa.eu/sides/getDoc.do?pubRef=-//EP//TEXT+TA+P6-TA-2009-

0389+0+DOC+XML+V0//EN (accessed February 17th, 2014).

http://www.oneofus.eu/ (accessed February 17th, 2014).

http://www.oneofus.eu/initiative-explanation/ (accessed February 17th, 2014).

http://www.right2water.eu/ (accessed February 17th, 2014).

https://secure.ombudsman.europa.eu/en/atyourservice/secured/complaintform.faces (accessed February 17th, 2014).

www.more-democracy-in-europe.org/sites/more-democracy-in-europe.org/files/u293/diaufruf-englisch-2-seitig.pdf (accessed February 17th, 2014).

www.yale.edu/leitner/resources/docs/2001-26.pdf. (accessed February 17th, 2014). 
